\title{
On the Psychological Realism of A Streetcar Named Desire
}

\author{
Xuefei Wang ${ }^{1}$ and Shuai $\mathrm{Han}^{2}$ \\ ${ }^{1}$ Economic and Technological development zones, Changchun, China \\ ${ }^{2}$ Residential building of Ji Lin University, Changchun, China \\ a 163595150@qq.com, b165007605@qq.com
}

Keywords: Tennessee williams; A Streetcar Named Desire; Psychological realism

\begin{abstract}
As a famous novel of the American literature, A Streetcar Named Desire represents Tennessee Williams' utmost achievement in fiction. Researchers are familiar with his undisguised description about symbolism in the novel, but less attention to the psychological realism in the novel. Psychological realism is the realistic writing that probes deeply into the complexities of characters' thoughts and motivations. Henry James is considered the founder of psychological realism. His novel The Ambassadors is considered to be a masterpiece of psychological realism. Tennessee Williams uses the psychological realism successfully in his play A Streetcar Named Desire. The thesis introduces the author of A Streetcar Named Desire, makes a research of his writing style by collecting and analyzing some of his works and expounds the background of this novel. The thesis used qualitative research techniques. The main purpose of this thesis is through the analysis of setting, characters, dialogue of work to show the psychological realism in A Streetcar Named Desire.
\end{abstract}

\section{Introduction}

Tennessee Williams is one of America's foremost $20^{\text {th }}$ century playwrights and the author of more than 70 plays, and he achieved his first successes with the productions of The Glass Menagerie (1945) and A Streetcar Named Desire (1947; Pulitzer Prize).In these plays, as in many of his later works, Williams explores the intense passions and frustrations of a disturbed and frequently brutal society. Unable to write openly about his homosexuality in the 1950s and 1960s, he displaced the imagined and experienced pleasures and pains of sexual relations from the autobiographical into nominally heterosexual dramas. Williams is perhaps most successful in his portraits of the hypersensitive and lonely southern woman, such as Blanche in streetcar. One of famous plays of Williams is A Streetcar Named Desire. This play is also called a psychological novel, because of its psychological realism[1,2].

Realism, a mode of writing that gives the impression of recording or 'reflecting' faithfully an actual way of life. The term refers, sometimes confusingly, both to a literary method based on detailed accuracy of description (i.e. verisimilitude) and to a more general attitude that rejects idealization, escapism, and other extravagant qualities of romance in favor of recognizing soberly the actual problems of life[3].

\section{Tennessee Williams and a Streetcar Named Desire}

Tennessee Williams found inspiration in his problematic family for much of his writing. In 1927, at the age of 16, Williams won third prize (five dollars) for an essay published in Smart Set entitled, "Can a Good Wife Be a Good Sport?" A year later, he published "The Vengeance of Nitocris" in Weird Tales. By then, Williams had written Cairo, Shanghai, Bombay!. This work was first performed in 1935 at 1780 Glenview in Memphis. He began writing A Streetcar Named Desire (1947) while living at 632 St. Peter Street. He finished it later in Key West, Florida, where he lived 
in a separate building at the home of a family named Black. Mr. Black became one of his gay partners, and they were close for many years, even after George and his family moved to Miami. It has been suggested that this Mr. Black was the inspiration for the film John Q. Tennessee was close to his sister Rose, a slim beauty whose sad life had perhaps the greatest influence on him. She was diagnosed with schizophrenia at a young age. As was common then, Rose was institutionalized and spent most of her adult life in mental hospitals. Performed in 1937 in Washington, D.C., the operation went badly. Rose's failed lobotomy was a hard blow to Williams. He never forgave their parents for allowing the operation. His sister's severe illness and failed surgery may have contributed to his alcoholism and his dependence on various combinations of amphetamines and barbituates often prescribed by Dr. Max (Feelgood) Jacobson. They may also have shared a genetic vulnerability, as Williams also suffered from depression. Williams' relationship with Frank Merlo, a second generation Sicilian American who had served in the U.S. Navy in World War II, lasted from 1947 until Merlo's death from cancer in 1963. With that stability, Williams created his most enduring works. Merlo provided balance to many of Williams' frequent bouts with depression and the fear that, like his sister Rose, he would go insane[4,5,6].

A Streetcar Named Desire (1951) is a subversive, steamy film classic that was adapted from Tennessee Williams' 1947 Pulitzer Prize-winning play (his first) of the same name. The themes of A Streetcar Named Desire: firstly, the play is about the reluctance or inability of people to accept the truth. Blanche lives in a cocoon of unreality to protect herself against her weaknesses and shortcomings. To preserve her ego, she lies about her promiscuous behavior in Laurel; she shuns bright light, lest it reveal her physical imperfections; and she refuses to acknowledge her problem with alcohol. Stanley effectively penetrates her cocoon verbally with his crude insults and physically with his sexual coup de main near the end of the play. Stanley has his own problem: he lacks the insight to see what he really is a coarse, domineering macho man ruled by primal instincts. Unlike Blanche, though, he is happy in his ignorance. For her part, Stella accepts the truth partly. She acknowledges that Stanley is crude and that her apartment is cramped and shabby. But, in the end, she refuses to accept the truth about her sister's past and about Stanley's violation of Blanche. "I couldn't believe Blanche's story about the rape and go on living with Stanley," Stella says; secondly, the play reflects the final destruction of the Old South, symbolized by Blanche and Belle Reve (the family property seized by creditors). This theme--not unlike that in Margaret Mitchell's Gone With the Wind, which begins to unfold in the opening scene of the play. Two women, one white and one black, sit as equals on the steps of an apartment building while Blanche arrives on scene accoutered in the attitude and finery of a southern belle of yesteryear. She is an alien, a strange creature from another time, another place; thirdly, the play maintains the despoliation of the sensitive and feminine by the feral and masculine. Blanche and her first husband, a homosexual, cannot survive in the world of Stanley and his kind. Stanley is a robust weed who grows in Blanche's carefully cultivated garden of lilies; fourthly, the play centers Unbridled sexual desire lead to isolating darkness and eventually death. Williams establishes this theme at the beginning of the play, when Blanche takes a streetcar named Desire (sex), transfers to one named Cemeteries (Death), and gets off at a street named Elysian Fields. He maintains the theme during the play with references to Blanche's first husband, a homosexual who committed suicide after she caught him with another man, and with Blanche's literal and figurative retreat into the shadows after having many sordid affairs. She shuns bright lights; she dates Mitch only in the evening; last, all that glitters is not gold. This Shakespearean motif manifests itself in Blanche's inability to grasp how Stanley and Stella can succeed at marriage without the finer things of life[7,8].

In this work, as in many of his later works, William explores the intense passions and frustrations of a disturbed and frequently brutal society. Unable to write openly about his homosexuality in the 1950s and 1960s, he displaced the imagined and experienced pleasures and pains of sexual relations from the autobiographical into nominally heterosexual dramas. 


\section{The psychological realism in A Streetcar Named Desire}

The psychological realism works, generally have these three features: First, the basis of these works is real.; Second, the works describe the social evil, psychological loneliness, psychological metamorphosis, hopeless mood is different, but all get going from the active awareness of social life, in order to create a more deep and beautiful spiritual world; Third, some of these works dilute epoch, desalt figures, but do not exclude awareness of reality, the reader can still feel the atmosphere and characteristics of the times. As a result, people called this creative thought as exoteric realism, or psychological realism.

As mentioned above, Williams used many psychological descriptions to show the characteristics of figures. In the following section will analyze the three main characters' inner worlds and show the psychological realism.

Blanche is a victim, but Blanche is anything but innocent. She was having sex with one of her high school English lit students back in Mississippi. It's not surprising that she got chased out of her small town teaching job. There's also the touching scene where she asks for and gets a kiss from the boy who is collecting for the newspaper. It's all tied in to her love for the boy who killed himself over her when she was 16 . Her fading beauty, vulnerability, and weakness can hardly help but elicit a sympathetic response. Blanche is the human condition writ large. In some respects there is some of Blanche in all of us: hidden ugliness from the past, both emotional and sexual neediness, and just plain old human weakness. Just express the one of the features of psychological realism that is the works describe the social evil, psychological loneliness, psychological metamorphosis, hopeless mood is different, but all get going from the active awareness of social life, in order to create a more deep and beautiful spiritual world. I do agree with at least one of the previous viewers that the term "nymphomaniac" seems somewhat out-of-date in describing Blanche. Blanche uses sex in a promiscuous fashion to escape from her loneliness. This is the same pathology that both men and women engage in when having "casual--such a strange contradiction in terms--sex". Certainly Williams didn't see her as either a "nympho" or a "slut". Rather, just a lonely, tortured individual[9].

Stella is living an unreal existence in regards to the way in which she likes to pretend she is living in a happy home. She's honest, kind, sexy, and very much in love with Stanley--despite his obvious faults. She also loves her sister and wants what's best for her. She and Blanche collude to some extent against Stanley which provides much of the work's strongest tensions. Stella is financially and emotionally dependent on Stanley, but she's also a strong character in her own right. We don't really know for sure if she'll go back to Stanley at the end of the novel after the baby and the sexual aggression against Blanche. We do know that Stanley for all her macho swagger is extremely emotionally dependent on her. Just express the one of the features of psychological realism that is the basis of these works is real. The figures' psychology, emotion and mood are the reflection and refraction that really survive in the heart of characters. Although figures' awareness, psychology is very unique, all have abundant connotation.

Through the behavior and the dialogue of Stanley we know his inner world. He wants to keep his position at home, which is the king of household. And he is afraid that Blanche will infect his status. Outside, Stanley is a strong man, has confident to control the whole family. But in his heart, the reality is he is quite afraid that he will lose the superiority complex. The basis of psychological novel is real.

\section{Conclusion}

After the publication of A Streetcar Named Desire Williams won the Pulitzer Prize and began to draw public and critical attention and became the focus in the contemporary critic circles. One of the reasons is that A Streetcar Named Desire differs greatly from the ever popular stories. On the surface, it contains all the elements common to that tradition, but, as a matter of fact, it has a very different ending. The topic discussed in this dissertation is selected on the basis of psychological realism. From the above analysis, the reader can see the developing process and the features of 
psychological realism, which derives from the description of the external world to the exploration on human's internal action, from the praise of the social conditions and systems to the criticism of the social values and historical viewpoints. This dissertation analyzes the three main characters inner worlds to show the psychological realism.

\section{References}

[1] Yaoxin Chang. A Survey of American Literature [M]. NanKai Uniwersity press, 1990.

[2] Tennessee Williams. Sweet Bird of Youth; A Streetcar Named Desire; The Glass Menagerie $[\mathrm{M}]$. Harmondsworth Penguinc, 1962

[3] Cunliffe Marcus. The Literiture of the United States [M]. $4^{\text {th }}$ ed.New York; Penguin Books, 1986

[4] Hornby, A .S. Oxford Advanced Learner's English to Chinese Dictionary [Z].Ed. Li Beida. Beijing: The Cummercial Press, 1972

[5] Xiaofang An. Overseas English[J].Analysis of Blanche's Tragedy Life in the Streetcar Named Desire,2014.(In Chinese)

[6] H.Y. Zhao. A brief history of English literature [M]. Communication University of China press,2000.(In Chinese)

[7] G.Q. Tu. Biography literature [M]. culture and Art Publishing House, 1984.(In Chinese)

[8] S.S. Yang. A Streetcar Named Desire [M]. Tsinghua University press, 1990.(In Chinese)

[9] Y. Zhang. "Harvard LAN-STAR bilingual guide" [A]. Tianjin science and Technology Translation Publishing Company, 1987.(In Chinese)

[10]Z.L. Hong, S.H. Xiao. British American drama [M]. Shanghai Foreign Language Press, 2000.(In Chinese) 